\title{
The Effect of High Temperature on Viability, Proliferation, Apoptosis and Anti-oxidant Status of Chicken Embryonic Fibroblast Cells
}

\section{EAuthor(s)

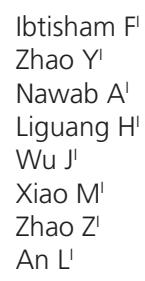

Agricultural Collage, Guangdong Ocean University, Zhanjiang, Guangdong, China.

Equally Contributed (Fahar Ibtisham, Yi Zhao)

\section{ABSTRACT}

The effects of oxidative stress induced by high temperature on the cell viability, proliferation, apoptosis and oxidative status of chicken embryonic fibroblasts (CEF) were analyzed. The viability, proliferation, apoptotic and anti-oxidative status were measured after incubating CEF at the temperatures of $37^{\circ} \mathrm{C}$ (control) and $40-44^{\circ} \mathrm{C}$ (experimental groups) for 6,12 and 24 hours. The results showed that at high temperature $\left(42-43^{\circ} \mathrm{C}\right)$, the viability of CEF cells decreased after 6 , 12 and $24 \mathrm{~h}$ of incubation, but the difference was significant only at $43^{\circ} \mathrm{C}$. Cell proliferation was significantly reduced at $44^{\circ} \mathrm{C} / 6 \mathrm{~h}$. The apoptotic rate of CEF cells was increased following heat treatments in a time-dependent manner. ROS formation increased with increasing temperature, but the difference was only significant at $44^{\circ} \mathrm{C} / 6,12 \mathrm{~h}$. Heat stress did not significantly affect the superoxide dismutase (SOD) activity. CAT activity was significantly decreased at $43^{\circ} \mathrm{C} / 24 \mathrm{~h}$ and $44^{\circ} \mathrm{C} / 12$ and $24 \mathrm{~h}$. Malondialdehyde (MDA) formation was significantly increased at $43^{\circ} \mathrm{C} / 12 \mathrm{~h}$ and $44^{\circ} \mathrm{C} / 12$ and $24 \mathrm{~h}$. In conclusion, heat stress induced the oxidative stress, decreasing the viability, proliferation and anti-oxidative response of CEF cells.

\section{INTRODUCTION}

Livestock are exposed to numerous types of stressors which disrupts their reproduction, production, and health. The continuously increasing ambient temperature is one of the most damaging stressors for livestock because of its detrimental effects, especially in poultry sector. In arid and tropical regions heat stress is considered as key because it directly and indirectly affects animal production and health.

In the poultry sector, high temperatures may significantly damage meat and egg production. Temperature has been suggested to be the most important factor controlling the embryonic and post-hatch development of chicks. Moreover, the negative effects of heat stress on animal growth performance also have been reported in the tropical and subtropical regions of the world. Reduced feed intake, daily gain, body weight, and growth rate were reported in broilers (Sohail et al., 2010). The reduction of feed intake of animals under heat stress is usually believed to be the primary reason for low production performance. However, it has lately been shown that high temperate change the steady state concentrations of free radicals, causing both mitochondrial and cellular oxidative damage.

High environmental temperature (physical stressor) challenges the homeostatic system and stimulates the excessive production of reactive oxygen species (ROS), which is a chemical stressor (Ibtisham et al., 2016). ROS are chemically-reactive molecules containing oxygen and are natural byproducts of the normal oxygen metabolism (Abdel- 
Ibtisham F, Zhao Y, Nawab A,

Liguang H, Wu J, Xiao M, Zhao Z, An L
The Effect of High Temperature on Viability, Proliferation, Apoptosis and Anti-oxidant Status of Chicken Embryonic Fibroblast Cells
Moneim et al., 2015). At normal physiological levels, ROS play an important role in hemostasis and cell signaling (Liu et al., 2015), but at high levels, ROS may promote apoptosis (Sinha et al., 2013). ROS cause irreversible damage to molecules as they enhance lipid peroxidation and damage protein and DNA, increasing the production of malondialdehyde (MDA) and thiobarbituric acid-reactive species (TBARS). MDA and TBARS can significantly damage cell structures(Di Meo et al., 2016). High environmental temperatures were shown to increase both of MDA and TBARS levels in broilers (Mujahid et al., 2005). Superoxide is the main ROS produced by mitochondria as an outcome of the reaction with oxygen molecules presenting unpaired electrons (Zolkipli-Cunningham \& Falk, 2017). In general, cells maintain a balance between ROS formation and elimination, whereas imbalances lead to oxidative stress. Under oxidative stress, the body protects itself against damages caused by ROS through enzymes, including catalases, lactoperoxidases, superoxide dismutases (SODs), glutathione peroxidases and peroxiredoxins (Michiels et al., 1994). Antioxidant enzyme activities are enhanced as a result of increasing ROS levels in order to maintain the steady state concentrations of generated free radicals. Furthermore, studies showed that concentrations of endogenous antioxidants, such as catalase and glutathione, decrease when environmental temperature is high (Kumar et al., 2011). This is due to the mobilization of cellular antioxidants to detoxify free radicals produced by high temperature. SOD transfer the superoxide produced as the key ROS into hydrogen peroxide and subsequently, glutathione peroxidase and catalase detoxify it. Avian species have comparatively lower ROS loads then mammals (Lu \& Finkel, 2008), which explains the longer life span potential of most bird species compared with mammals with similar body weight (Barja, 1998).

Hyperthermia is cytotoxic, because it modifies metabolic reactions and biological molecules, causing oxidative cell damage and triggering both apoptosis and necrosis pathways. Hyperthermia upregulates ROS production, which subsequently triggers the fundamental pathway of the apoptosis progression, which is a mitochondrial pathway based on cytochrome c liberation from the outer mitochondrial membrane (Du et al., 2008). Indeed, several researchers have demonstrated that heat stress triggers cell necrosis (Shimizu et al., 1996).

Both chronic and acute heat stress cause different effects on metabolism and production. Researchers involved in studies on hyperthermia are trying to produce special animal breeds either via genomic selection (Ibtisham et al., 2017) or by determining the molecular and cellular responses of animals under heat stress condition, and are also trying to explore how animals can be managed in hot environments. This means that being able to better characterize the cell response by different heat stress in terms of duration or intensity is of great interest. The study of these fundamental molecular and cellular routes may provide methods to select high temperature-tolerant animals with great production potential. Among the various biological tools that have been used to study the stress response, avian cells grown in tissue culture have shown to be very valuable. Chicken embryo fibroblast (CEF) cells are commonly used in embryology and differentiation studies, as well as in vaccine production (Jeon et al., 2016). The objective of the current study was to determine the effects of high temperature on the proliferation, apoptosis and antioxidant status of CEF.

\section{MATERIALS AND METHODS}

\section{Materials}

HEPES and dimethyl sulfoxide (DMSO), MTT and Cell Counting Kit (CCK-8) were purchased from Sigma Aldrich Chemicals (St. Louis, MO, USA). PhosphateBuffered Saline (PBS), Dulbecco's Modified Eagle's Medium (DMEM), fetal bovine serum (FBS), trypsinEDTA and penicillin-streptomycin were purchased from Gibco, Invitrogen (Carlsbad, CA, USA). Catalase (CAT), superoxide dismutase (SOD), malondialdehyde (MDA) and reactive-oxygen species (ROS) kits were purchased from Nanjing Institute of Bioengineering, Nanjing, China. All other chemicals used were of high purity biochemistry grade.

\section{Cell Culture}

Primary CEF cells were prepared using nine-day old embryos isolated from Lohmann chicken embryos. The cells were trypsinized and collected by centrifugation. Primary CEF cells and land continuous CEF cell line were cultured in DMEM with $10 \% \mathrm{FBS}$ at $37^{\circ} \mathrm{C}$ in a humidified incubator under $5 \% \mathrm{CO}_{2}$ and $95 \%$ air. Upon confluence, the cells were purified via serial passages. Experimental cells were used in exponential phase and from passages 3-6.

Cultured CEF cells plates were divided into six groups (four replicates each), including a control group (NC) and five experimental groups $(\mathrm{H} 1, \mathrm{H} 2, \mathrm{H} 3$, $\mathrm{H} 4$, and $\mathrm{H} 5$ ). Experimental plates were moved to a 
Ibtisham F, Zhao Y, Nawab A,

Liguang H, Wu J, Xiao M, Zhao Z, An L
The Effect of High Temperature on Viability,

Proliferation, Apoptosis and Anti-oxidant Status of Chicken Embryonic Fibroblast Cells separate incubator $\left(95 \%\right.$ air $\left./ 5 \% \mathrm{CO}_{2}\right)$ at the desired experimental temperature $\left(40^{\circ}, 41^{\circ}, 42^{\circ}, 43^{\circ}\right.$ and $44^{\circ}$, respectively), whereas $N C$ group plates remained at $37^{\circ} \mathrm{C}$

\section{Cell Viability and Proliferation Assay}

For the measurement of cell viability and proliferation, CEF cells were cultured in 96-well culture plates at a density of $10^{4} \mathrm{cell} / \mathrm{s} / \mathrm{cm}^{2}$, with the heat stress experimental plates being transferred to the variable temperature cell culture incubator following $24 \mathrm{~h}$ of attachment. After 6, 12 and $24 \mathrm{~h}$ of heat stress treatment, cells were separately incubated in medium containing $1.25 \mathrm{mg} / \mathrm{mL}$ of the $10 \mathrm{ul}$ MTT salt, and $10 \mu \mathrm{L}$ CCK-8, for 4hoursand 2 hours, respectively, at $37^{\circ} \mathrm{C}$. After an incubation period of 4 hours at $37^{\circ} \mathrm{C}$, formazan was solubilized by adding DMSO. The optical densities were measured at $490 \mathrm{~nm}$ (Wei et al., 2012).

\section{Analysis of Apoptosis by Annexin V-FITC/ Propidium lodide Staining}

Samples were labeled with annexin $\mathrm{V}$-fluorescein isothiocyanate (FITC; BD Biosciences, San Diego, CA) and propidium iodide (PI) double staining (Zhang et al., 1997) according to the manufacturer's instructions. Briefly, CEF cells were cultured in 96-well culture plates at a density of $10^{4}$ cells $/ \mathrm{cm}^{2}$, with the temperature experimental plates being transferred to the variable temperature cell culture incubator following $24 \mathrm{~h}$ of attachment. After 6,12 and $24 \mathrm{~h}$ of heat stress treatment, cells were incubated in $500 \mu \mathrm{L}$ of binding buffer with AnnexinV-FITC/PI in dark for 20 min, and following samples were analyzed by fluorescence microscope.

\section{Antioxidant Activity Measurement}

After the heat stress treatment, CEF cells were washed twice with PBS. Cells were then incubated with $0.2 \%$ tritonx-100, at $4^{\circ}$ for $30 \mathrm{~min}$. Cells were ruptured with ultrasonic cell oscillators and SOD activity, CAT activity, MAD and ROS content were measured using respective assay kits obtained from Nanjing Jiancheng Bioengineering Institute (strictly according to kit manufacturer protocol).

\section{Statistical Analysis}

Data were analyzed using the software SPSS (version 20.0) (Chen et al., 2017) and Duncan's multiple range test was applied to test the difference among groups. Differences were considered significant when $p<0.05$. All the results are expressed as means \pm standard error.

\section{RESULTS}

\section{Effect of Different Temperatures on CEF Cell Viability}

The viability of CEF cells was measured at 6,12 , and $24 \mathrm{~h}$ after heat stress $\left(40,41,42,43\right.$ or $\left.44^{\circ} \mathrm{C}\right)$ and control $\left(37^{\circ} \mathrm{C}\right)$ treatments. Table 1 lists the effect of heat stress on the viability of CEF cells. After $6 \mathrm{~h}$ of heat stress, cell viability of $\mathrm{H} 1, \mathrm{H} 4$ and $\mathrm{H} 5$ treatments were reduced compared with the NC, but the difference was not significant. After $6 \mathrm{~h}$ of heat stress treatment, H3 presented significantly lower number of viable cells

Table1 - Effect of different temperatures on the viability of chicken embryonic fibroblasts.

\begin{tabular}{lccccccc}
\hline Parameter & Duration $(h)$ & NC & $H 1$ & $H 2$ & $H 3$ & $H 4$ & $H 5$ \\
\hline \multirow{2}{*}{ MTT } & 6 & $0.210 \pm 0.018$ & $0.201 \pm 0.009$ & $0.272 \pm 0.007^{*}$ & $0.179 \pm 0.009^{*}$ & $0.182 \pm 0.012$ & $0.191 \pm 0.009$ \\
(OD) & 12 & $0.205 \pm 0.018$ & $0.195 \pm 0.030$ & $0.255 \pm 0.041^{*}$ & $0.181 \pm 0.017^{*}$ & $0.197 \pm 0.020$ & $0.176 \pm 0.012^{*}$ \\
& 24 & $0.187 \pm 0.058$ & $0.195 \pm 0.011$ & $0.215 \pm 0.015^{*}$ & $0.152 \pm 0.027$ & $0.167 \pm 0.027$ & $0.119 \pm 0.013^{*}$ \\
\hline
\end{tabular}

*Indicates significant differences among treatments $(p<0.05)$

compared with NC. Comparing cell groups at 12 h, the viability of $\mathrm{H} 3$ and $\mathrm{H} 5$ cells were significantly lower compared with NC. At $24 \mathrm{~h}$ of treatment, only $\mathrm{H} 5$ group had significantly lower number of viable cells compared to NC group. $\mathrm{H} 2$ cells presented significantly higher viability compared with NC at 6,12 and $24 \mathrm{~h}$ of treatment.

\section{Effect of Different Temperatures on CEF Cell Proliferation}

The effects of heat stress on the proliferation of CEF cells are shown in Table 2. Cell proliferation was examined using Cell Counting Kit- 8 at the time points of 6,12 and $24 \mathrm{~h}$ after heat stress. After $6 \mathrm{~h}$ of heat stress, the proliferation of $\mathrm{H} 2$ group cells was significantly higher and of $\mathrm{H} 5$ cells was significantly lower compared with NC cells. By 12 h of treatment, no statistical differences in proliferation were detected among treatments. The $\mathrm{H} 5$ group exhibited reduced proliferation compared to NC, but the difference was not significant. At $24 \mathrm{~h}$, the proliferation of $\mathrm{H} 1, \mathrm{H} 3$, $\mathrm{H} 4$, and $\mathrm{H} 5$ cells was not statistically different from NC cells. The H2 group showed significantly higher proliferation compared with NC at $24 \mathrm{~h}$. 
Table2 - Effect of different temperatures on the proliferation of chicken embryonic fibroblasts.

\begin{tabular}{lccccccc}
\hline Parameter & Duration $(\mathrm{h})$ & $\mathrm{NC}$ & $\mathrm{H} 1$ & $\mathrm{H} 2$ & $\mathrm{H}$ & $\mathrm{H} 4$ & $\mathrm{H} 5$ \\
\hline \multirow{2}{*}{ CCK8 } & 6 & $0.177 \pm 0.010$ & $0.215 \pm 0.57$ & $0.238 \pm 0.66^{*}$ & $0.214 \pm 0.031$ & $0.187 \pm 0.031$ & $0.128 \pm 0.031^{*}$ \\
(OD) & 12 & $0.225 \pm 0.032$ & $0.226 \pm 0.40$ & $0.259 \pm 0.067$ & $0.235 \pm 0.023$ & $0.233 \pm 0.017$ & $0.214 \pm 0.018$ \\
& 24 & $0.185 \pm 0.023$ & $0.178 \pm 0.39$ & $0.215 \pm 0.36^{*}$ & $0.177 \pm 0.014$ & $0.171 \pm 0.012$ & $0.163 \pm 0.012$ \\
\hline
\end{tabular}

*Indicates significant differences among treatments $(p<0.05)$

\section{Effect of Different Temperatures on ROS Production}

In order to evaluate heat stress-induced cell toxicity, intracellular ROS generation using a ROS kit (Nanjing Jiancheng Bioengineering Institute, China) was analyzed. Table 3 lists the effect of heat stress on ROS production. At $6 \mathrm{~h}, \mathrm{H} 1$ and $\mathrm{H} 2$ group showed lower ROS content compared to NC, but the difference was not significant. $\mathrm{H} 3, \mathrm{H} 4$, and $\mathrm{H} 5$ groups presented higher ROS content compared with NC, but the difference was not significant. By $12 \mathrm{~h}$ of heat treatment, the $\mathrm{H} 2$ group showed lower ROS level compared to NC. H3, $\mathrm{H} 4$, and $\mathrm{H} 5$ had a higher level of ROS content compared to $\mathrm{NC}$, but only $\mathrm{H} 5$ showed a significant difference. At 24h, H2, H3, H4, and $\mathrm{H} 5$ exhibited a higher level of ROS compared to NC, but the difference was only significant for the $\mathrm{H} 4$ and $\mathrm{H} 5$ groups.

Table 3 - Effect of different temperatures on ROS content of chicken embryonic fibroblasts.

\begin{tabular}{lcccccccc}
\hline Parameter & Duration $(\mathrm{h})$ & $\mathrm{NC}$ & $\mathrm{H} 1$ & $\mathrm{H} 2$ & $\mathrm{H} 3$ & $\mathrm{H} 4$ & $\mathrm{H} 5$ \\
\hline \multirow{2}{*}{ ROS } & 6 & $63.91 \pm 8.64$ & $60.48 \pm 7.36$ & $62.91 \pm 4.50$ & $67.00 \pm 4.05$ & $70.91 \pm 8.50$ & $73.48 \pm 20.36$ \\
& 12 & $95.22 \pm 5.28$ & $95.59 \pm 7.40$ & $90.84 \pm 6.54$ & $105.54 \pm 10.92$ & $112.84 \pm 6.54$ & $120.59 \pm 7.40^{*}$ \\
& 24 & $130.91 \pm 4.22$ & $129.48 \pm 7.36$ & $134.99 \pm 6.64$ & $156.48 \pm 10.36$ & $167.01 \pm 8.64^{*}$ & $189.18 \pm 9.06^{*}$ \\
\hline
\end{tabular}

*Indicates significant differences among treatments $(p<0.05)$

\section{Effect of Different Temperatures on CEF Cell Apoptosis}

In order to examine the effect of heat stress on CEF cells apoptosis in vitro, Annexin V-FITC (green)/ Propidium lodide (red) staining was performed on CEF cells exposed to the different temperature $(37,40-$ $45^{\circ} \mathrm{C}$ ) at 6,12 and $24 \mathrm{~h}$. The apoptosis of CEF cells submitted to heat stress increased in a time-dependent manner (Figure $1 \mathrm{~A}, 1 \mathrm{~B}$ and $\mathrm{C}$ ). $\mathrm{H} 1$ and $\mathrm{H} 2$ groups showed lower numbers of apoptotic cells compared to $\mathrm{H} 3, \mathrm{H} 4$, and $\mathrm{H} 5$.

\section{Effect of Different Temperatures on Anti- oxidant Status}

The effects of heat stress on CAT, SOD activity, and MDA content are shown in Table 4. At 6 h, H2 and
H3 group showed improved CAT activity, while $\mathrm{H} 4$ and $\mathrm{H} 5$, reduced activity. At 12 h, H5 showed significantly decreased CAT activity compared with NC. At 24 h, H1 and $\mathrm{H} 2$ presented higher CAT activity, while $\mathrm{H} 4$ and H5 showed significantly lower activity compared with NC. Heat stress did not significantly affect SOD activity. At 6 h, MDA content was lower in $\mathrm{H} 1$ and $\mathrm{H} 2$, and significantly higher in $\mathrm{H} 5$ group compared with NC. By 12 h, H4 and H5 had significantly increased MDA content compared to NC.

\section{DISCUSSION}

Hyperthermia is considered as key threat to animal health and it has been shown to have a significant economic impact on the poultry industry,

Table 4 - Effect of different temperatures on antioxidant activity of chicken embryonic fibroblasts.

\begin{tabular}{lccccccc}
\hline Parameter & Duration $(\mathrm{h})$ & $\mathrm{NC}$ & $\mathrm{H} 1$ & $\mathrm{H} 2$ & $\mathrm{H} 3$ & $\mathrm{H} 4$ & $\mathrm{H} 5$ \\
\hline & 6 & $18.91 \pm 1.64$ & $18.48 \pm 2.36$ & $20.91 \pm 2.50$ & $19.00 \pm 1.05$ & $16.91 \pm 2.50$ & $13.48 \pm 4.36$ \\
CAT & 12 & $35.22 \pm 3.24$ & $38.59 \pm 4.40$ & $37.84 \pm 3.54$ & $35.54 \pm 4.92$ & $32.84 \pm 2.54$ & $19.59 \pm 6.40^{*}$ \\
$(\mathrm{U} / \mathrm{mL})$ & 24 & $53.91 \pm 4.22$ & $60.48 \pm 7.36$ & $58.99 \pm 6.64$ & $50.48 \pm 10.36$ & $44.01 \pm 8.64^{*}$ & $20.18 \pm 8.26^{*}$ \\
& 6 & $63.91 \pm 8.64$ & $60.48 \pm 7.36$ & $62.91 \pm 4.50$ & $67.00 \pm 4.05$ & $60.91 \pm 8.50$ & $56.48 \pm 20.36$ \\
$\mathrm{SOD}$ & 12 & $75.22 \pm 5.28$ & $75.59 \pm 7.40$ & $80.84 \pm 6.54$ & $72.54 \pm 10.92$ & $74.84 \pm 6.54$ & $70.59 \pm 7.40$ \\
$(\mathrm{U} / \mathrm{mL})$ & 24 & $80.91 \pm 4.22$ & $79.48 \pm 7.36$ & $84.99 \pm 6.64$ & $76.48 \pm 10.36$ & $67.01 \pm 8.64$ & $69.18 \pm 9.06$ \\
& 6 & $0.35 \pm 0.11$ & $0.33 \pm 0.10$ & $0.30 \pm 0.09$ & $0.36 \pm 0.10$ & $0.49 \pm 0.16$ & $0.57 \pm 0.15^{*}$ \\
$\mathrm{MDA}$ & 12 & $0.75 \pm 0.11$ & $0.68 \pm 0.14$ & $0.70 \pm 0.19$ & $0.78 \pm 0.15$ & $0.90 \pm 0.19^{*}$ & $0.92 \pm 0.12^{*}$ \\
$(\mathrm{nmol} / \mathrm{mL})$ & 24 & $1.35 \pm 0.11$ & $1.36 \pm 0.14$ & $1.28 \pm 0.19$ & $1.38 \pm 0.15$ & $1.40 \pm 0.19$ & $1.34 \pm 0.12$ \\
\hline
\end{tabular}

*Indicates significant differences among treatments $(p<0.05)$ 
Ibtisham F, Zhao Y, Nawab A,

Liguang H, Wu J, Xiao M, Zhao Z, An L
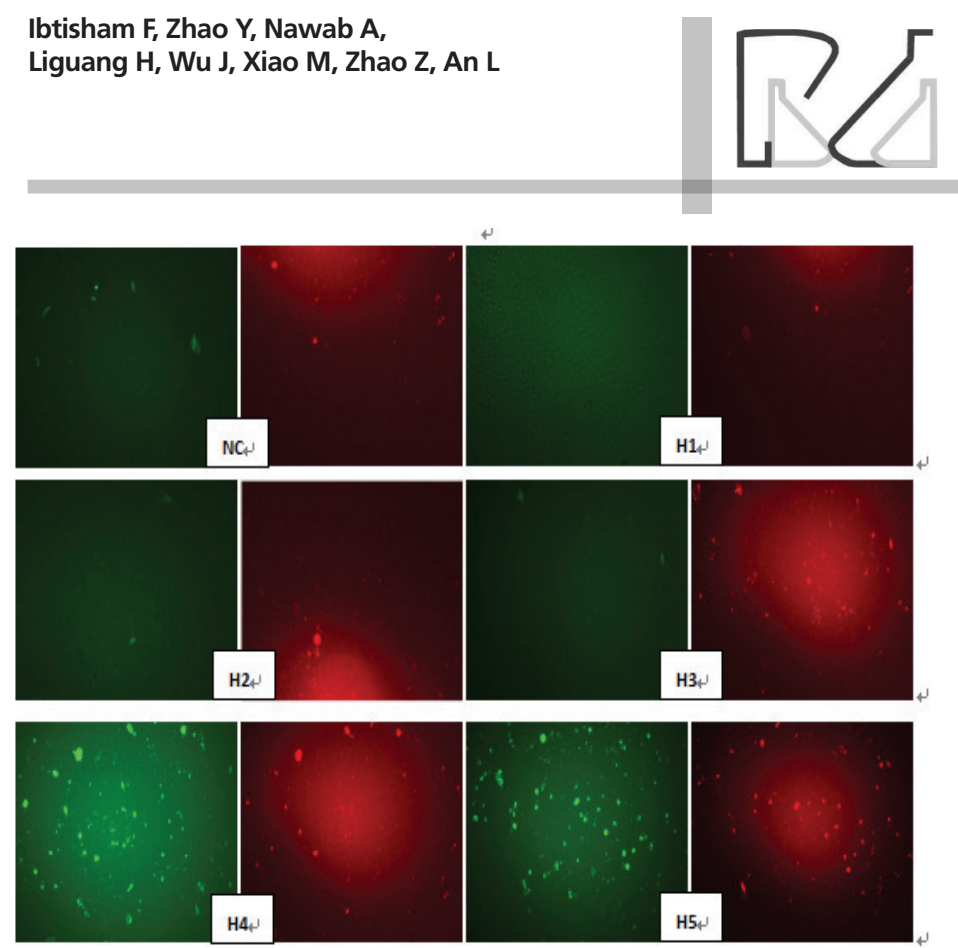

Figure $1 \mathbf{A}$ - Effects of different temperature treatments on the apoptosis of chicken embryonic fibroblasts measure at 6 h(Annexin V-FITC -green/Propidium lodide-red)
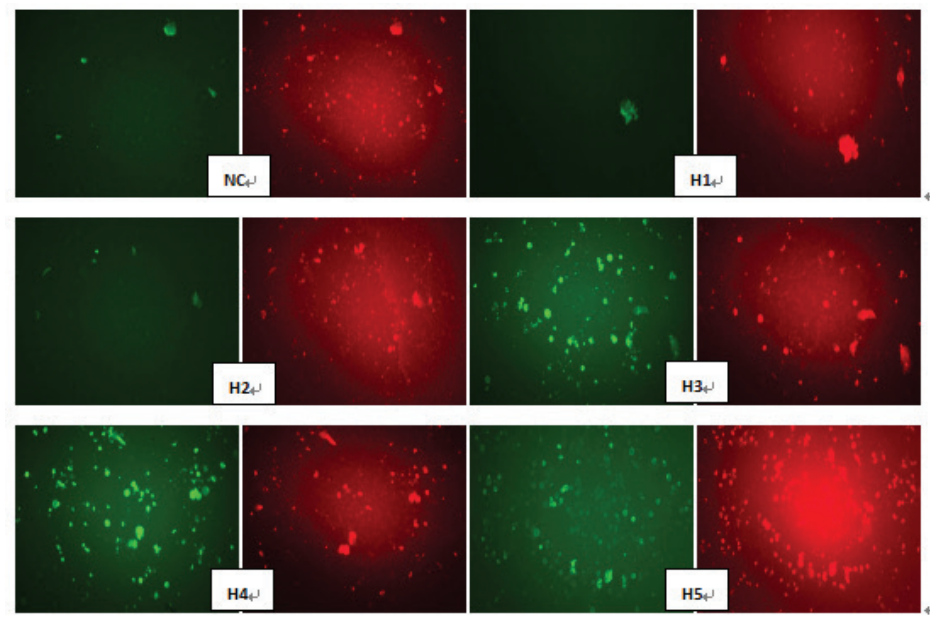

Figure 1 B - Effects of different temperature treatments on apoptosis of chicken embryonic fibroblasts cells at $12 \mathrm{~h}$ (Annexin V-FITC -green/Propidium lodide-red)
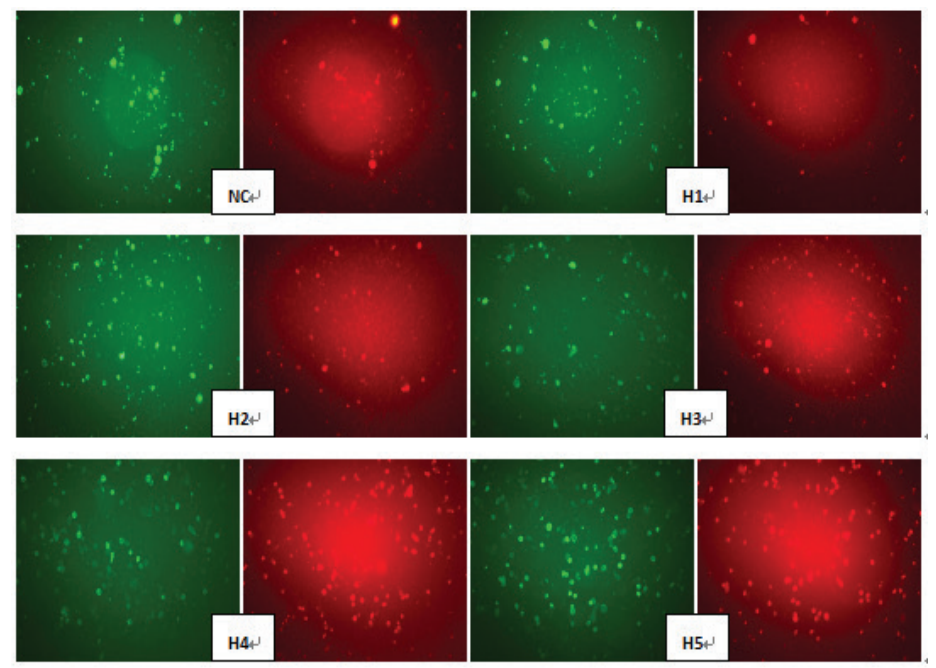

Figure $1 \mathbf{C}$ - Effects of different temperature treatments on apoptosis of chicken embryonic fibroblasts cells at $24 \mathrm{~h}$ (Annexin V-FITC -green/Propidium lodide-red)
The Effect of High Temperature on Viability, Proliferation, Apoptosis and Anti-oxidant Status of Chicken Embryonic Fibroblast Cells

and the losses are estimated to increase due to the rising environmental temperature around the globe. However, little is known about physiological response of chickens under heat stress. Therefore, the purpose of this study was to advance our understanding of cellular responses that may compromise the performance of chickens during heat stress. Collectively, the obtained results show that high temperatures induce oxidative stress, resulting in lower cell viability and proliferation and reduced anti-oxidative response of CEF cells.

Heat stress is physical stressor that may induce structural changes in proteins, leading to cell death. In the current study, heat stress-induced cytotoxicity was assessed using MTT, which confirmed that cell viability was greatly decreased under heat stress. The damage caused by the different temperatures was timedependent. Although at $6 \mathrm{~h}$ of heat stress the viability of the CEF cells was not severely affected, the $\mathrm{H} 2$ group presented significantly higher cell viability compared with NC. At 12 and 24 h, H2 had significantly higher cell viability, while $\mathrm{H} 5$ showed significant lower cell viability compared with NC. This reduced cell viability as temperature increased temperate is in agreement with a previous study on the effect of heat stress on avian cells (Harding et al., 2016), human mesenchymal stromal cells (Reissis et al., 2013), mammalian epithelial cells (Du et al., 2008), and fish hepatic cells (Cui et al., 2013). Our results showed that like viability, the proliferation of CEF was also decreased when cells were maintained at high temperature for $24 \mathrm{~h}$. Higher CEF proliferation was observed in the experimental groups $\mathrm{H} 1, \mathrm{H} 2, \mathrm{H} 3$, and $\mathrm{H} 4$ at 6 and $12 \mathrm{~h}$. The results presented in this study provide the evidence of the beneficial effects of mild heat shock for a short duration on the viability and proliferation of CEF. This type of beneficial effects were also previously reported in human mesenchymal stromal cells (Choudhery et al., 2015), where mild heat shock enhanced proliferation. Such results are useful for the development of safe strategies for the maintenance of cell potential when expansion is required for cell-based therapies.

Homeostasis is continually challenged by intrinsic and extrinsic adverse forces or stressors. A stressful condition can stimulate ROS production and induce oxidative stress in cells, triggering protein and DNA oxidative damage as well as lipid peroxidation (Lin, Decuypere and Buyse, 2006). ROS has been associated with the number of pathological conditions, including infertility, bone disorders, ischemic/ reperfusion injury, rheumatoid arthritis, cataract, diabetic nephropathy, neurological disorders and 
Ibtisham F, Zhao Y, Nawab A,

Liguang H, Wu J, Xiao M, Zhao Z, An L
The Effect of High Temperature on Viability, Proliferation, Apoptosis and Anti-oxidant Status of Chicken Embryonic Fibroblast Cells aging by means of lipid peroxidation (Jin et al., 2011). In the present study, ROS level increased with high temperature $\left(42-44^{\circ} \mathrm{C}\right)$ and the CEF group exposed to $44^{\circ} \mathrm{C}$ presented significantly higher ROS level at $24 \mathrm{~h}$. Previous studies reported that high temperature induces ROS production in fibroblasts (Grasso et al., 2003), platelets (Wang et al., 2013), leukemia cells (Katschinski et al., 2000), skeletal muscle cells (Mujahid et al., 2005) and diaphragm muscle cells (Zuo et al., 2000). Mitochondrial injury is considered as an attractive source for the excessive production of ROS, which can promote apoptotic signaling (Orrenius, Gogvadze and Zhivotovsky, 2007). As temperature increases the frequency of biological and numerous chemical reactions increase, resulting in elevated body temperature, which in turn increases ROS production by enhancing metabolic reactions in cells. Hence, it is proposed that the upregulated production of ROS and the subsequent oxidative stress are partially responsible for heat-induced cellular damage. In the present study, we also found, as temperature increased, more ROS was produced, leading to higher apoptosis of CEF cells. The apoptotic cell ratio of CEF cells increased with heat treatments in a time-dependent manner. The heat treatment at $43^{\circ} \mathrm{C}$ for $6 \mathrm{~h}$ did not increase apoptosis compared with the control group. Annexin V-FITC/Propidium lodide staining showed that the number of apoptotic cells increased as temperature and the duration of heat stress increase. Several conditions, molecules, and organelles may be involved in apoptosis and ROS may play a key role in apoptosis (Wang et al., 2008). Our finding are in agreement with previous studies reporting that heat stress induced apoptosis in chicken myocardial cells (Xu et al., 2017), human umbilical vein endothelial cells (Li et al., 2015)hepatocytes and hepatocellular carcinoma cells (Thompson et al., 2014), and rat germ cells (Lizama et al., 2009).

Under normal physiological states, the balance between ROS production and destruction is well regulated in cell metabolism. ROS is promptly removed by antioxidant enzymes, such as CAT, SOD, and nonenzymatic defenses, such as tocopherol, amino acids, and vitamins $E$, K, and C (Cheng et al., 2015). When ROS is excessively produced under stress conditions, antioxidant defense systems play an impotent role to protect cells from oxidative damage. Under oxidative stress, SOD works as the primary defense line, modifying highly reactive superoxide radicals into less toxic hydrogen peroxides, which are subsequently decomposed by CAT.
It is believed that heat stress not only elevates ROS production, but also disturbs antioxidant systems in Japanese quails (Sahin et al., 2003) laying hens (XiaoLan et al., 2012), broiler chickens (Lin, Du \& Zhang, 2000). This is why oxidative stress has been linked with both ROS production and changes in the scavenging ability of antioxidant systems (Lin et al., 2008). In present study, the activities of SOD and CAT were reduced at $6 \mathrm{~h}$ of heat stress in the $\mathrm{H} 2$ and $\mathrm{H} 3$ groups, and at $24 \mathrm{~h}$ of heat stress, CAT and SOD activities were increased in the $\mathrm{H} 1$ and $\mathrm{H} 2$ groups. Under mild oxidative stress, SOD and CAT activities increase, but are reduced when oxidative stress is extended (Igor $M$ et al., 2016), which explains why $H 1, H 2$, and $H 3$ groups presented better activity of these enzymes comparatively to NC. On the other hand, the groups submitted to higher temperatures $(\mathrm{H} 4$ and $\mathrm{H} 5)$ showed reduced SOD and CAT activities, possibly due to the consumption or inhibition of antioxidant synthesis by ROS.

The content of MDA of $\mathrm{H} 5$ cells at $6 \mathrm{~h}$ of heat stress and of $\mathrm{H} 4$ and $\mathrm{H} 5$ at 12 and $24 \mathrm{~h}$ of heat stress was significantly higher compares with NC. The increase in MDA content also demonstrates that heat stress induced oxidative stress in CEF cells as a result of lipid peroxidation and protein and DNA damage (Di Meo et al., 2016). Together, these results showed that heat stress reduced the activity of the enzymatic scavenging systems.

In conclusion, the results of present study indicate that heat stress stimulates ROS production, and its excessive accumulation reduces cell viability and proliferation and induces apoptosis. Furthermore, excessive ROS production caused by heat stress also reduces the activity of antioxidant defense systems, leading to increased oxidative damage of chicken embryonic fibroblast cells. The information presented in this study may aid the elucidation of the mechanism apoptosis and oxidative stress induced by heat stress in avian cells.

\section{ACKNOWLEDGEMENTS}

This work was supported by the Science and Technology Planning Project of Guangdong Province, China (2010 B090400376).

\section{COMPETING INTERESTS}

The authors declare that they have no competing interests. 


\section{REFERENCES}

Abdel-Moneim AM, Al-Kahtani MA, El-Kersh MA, Al-Omair MA. free radicalscavenging, anti-inflammatory/anti-fibrotic and hepatoprotective actions of taurine and silymarin against $\mathrm{CCl} 4$ induced rat liver damage. Plos One 2015;10:e0144509.

Barja G. Mitochondrial free radical production and aging in mammals and birds. Annals of the New York Academy of Sciences 1998;854:224238.

Chen Y, Zeng L, Yang J, Wang Y, Yao F, Wu Y, et al. Anti-DHAV-1 reproduction and immuno-regulatory effects of a flavonoid prescription on duck virus hepatitis. Pharmaceutical Biology 2017;55:1545-1552.

Cheng C-H, Yang F-F, Liao S-A, Miao Y-T, Ye C-X, Wang A-L, et al. High temperature induces apoptosis and oxidative stress in pufferfish (Takifugu obscurus) blood cells. Journal of Thermal Biology 2015;53:172-179.

Choudhery MS, Badowski M, Muise A, Harris DT. Effect of mild heat stress on the proliferative and differentiative ability of human mesenchymal stromal cells. Cytotherapy 2015;17:359-368.

Cui Y, Liu B, Xie J, Xu P, Tsion HMH, Zhang Y. The effect of hyperthermia on cell viability, oxidative damage, and heat shock protein expression in hepatic cells of grass carp (Ctenopharyngodon idellus). Journal of Thermal Biology 2013;38:355-361.

Di Meo S, Reed TT, Venditti P, Victor VM. Role of ROS and RNS sources in physiological and pathological conditions. Oxidative Medicine and Cellular Longevity 2016;2016:1245049.

Du J, Di H-S, Guo L, Li Z-H, Wang G-L. Hyperthermia causes bovine mammary epithelial cell death by a mitochondrial-induced pathway. Journal of Thermal Biology 2008;33:37-47.

Grasso S, Scifo C, Cardile V, Gulino R, Renis M. Adaptive responses to the stress induced by hyperthermia or hydrogen peroxide inhuman fibroblasts. Experimental Biology and Medicine (Maywood, NJ) 2003;228:491-498.

Harding RL, Halevy O, Yahav S, Velleman SG. The effect of temperature on proliferation and differentiation of chicken skeletal muscle satellite cells isolated from different muscle types. Physiological Reports 2016;4:113.

Ibtisham F, Nawab A, Zhao Y, Li G, Xiao M, An L. effect of antimicrobial triclosan on reproductive system of male rat. Pharmaceutica Analytica Acta 2016;7:1-5.

Ibtisham F, Zhang L, Xiao M, An L, Bilal M. Genomic selection and its application in animal breeding. Thai Journal of Veterinary Medicine 2017;47:301-310.

Igor M P, Pavičić I, Mirta M, Ahmed LB, Babič M, Daniel H, et al. Oxidative stress response in neural stem cells exposed to different superparamagnetic iron oxide nanoparticles. International Journal of Nanomedicine 2016;11:1701-1715.

Jeon M, Choi H, Lee SI, Kim JS, Park M, Kim K, et al. GRP78 is required for cell proliferation and protection from apoptosis in chicken embryo fibroblast cells. Poultry Science 2016;95:1129-1136.

Jin DP, Li CY, Yang HJ, Zhang WX, Li CL, Guan WJ, et al. Apoptotic effects of hydrogen peroxide and vitamin $C$ on chicken embryonic fibroblasts: redox state and programmed cell death. Cytotechnology 2011;63:461.

Katschinski DM, Boos K, Schindler SG, Fandrey J. Pivotal role of reactive oxygen species as intracellular mediators of hyperthermia-induced apoptosis. The Journal of Biological Chemistry 2000;275:2109421098.
Kumar A, Singh G, Kumar BVS, Meur SK. Modulation of antioxidant status and lipid peroxidation in erythrocyte by dietary supplementation during heat stress in buffaloes. Livestock Science 2011;138:299-303.

Li L, Tan H, Gu Z, Liu Z, Geng Y, Liu Y, et al. Heat stress induces apoptosis through a ca2+-mediated mitochondrial apoptotic pathway in human umbilical vein endothelial cells. Plos One 2015;9:1-20.

Lin H, Decuypere E, Buyse J. Acute heat stress induces oxidative stress in broiler chickens. Comparative Biochemistry and Physiology Part A: Molecular \& Integrative Physiology 2006;144:11-17.

Lin H, Du R, Zhang ZY. Peroxide status in tissues of heat-stressed broilers. Asian Australasian Journal of Animal Sciences 2000;13:1373-1376.

Lin H, Vos D De, Decuypere E, Buyse J. Dynamic changes in parameters of redox balance after mild heat stress in aged laying hens (Gallus gallus domesticus). Comparative Biochemistry and Physiology Part C: Toxicology \& Pharmacology 2008;147:30-35

Liu F-W, Liu F-C, Wang Y-R, Tsai H-I, Yu H-P. Aloin protects skin fibroblasts from heat stress-induced oxidative stress damageby regulating the oxidative defense system. Plos One 2015;10:e0143528.

Lizama C, Lagos CF, Lagos-Cabré R, Cantuarias L, Rivera F, Huenchuñir P, et al. Calpain inhibitors prevent p38 MAPK activation and germ cell apoptosis after heat stress in pubertal rat testes. Journal of Cellular Physiology 2009;221:296-305

Lu T, Finkel T. Free radicals and senescence. Experimental Cell Research 2008;314:1918-1922.

Michiels C, Raes M, Toussaint O, Remacle J. Importance of Se-glutathione peroxidase, catalase, and Cu/Zn-SOD for cell survival against oxidative stress. Free Radical Biology \& Medicine 1994;17:235-248.

Mujahid A, Yoshiki Y, Akiba Y, Toyomizu M. Superoxide radical production in chicken skeletal muscle induced by acute heat stress. Poultry Science 2005;84:307-314.

Orrenius S, Gogvadze V, Zhivotovsky B. Mitochondrial oxidative stress: implications for cell death. Annual Review of Pharmacology and Toxicology 2007;47:143-183.

Reissis Y, García-Gareta E, Korda M, Blunn GW, Hua J. The effect of temperature on the viability of human mesenchymal stem cells. Stem Cell Research and Therapy 2013;4:139.

Sahin K, Onderci M, Sahin N, Gursu MF, Kucuk O. Dietary vitamin C and folic acid supplementation ameliorates the detrimental effects of heat stress in japanese Quail. The Journal of Nutrition 2003;133:1882-1886.

Shimizu S, Eguchi $Y$, Kamiike W, Waguri S, Uchiyama $Y$, Matsuda $H$, et al. Retardation of chemical hypoxia-induced necrotic cell death by Bcl2 and ICE inhibitors: possible involvement of common mediators in apoptotic and necrotic signal transductions. Oncogene 1996;12:20452050

Sinha K, Das J, Pal PB, Sil PC. Oxidative stress: the mitochondria-dependent and mitochondria-independent pathways of apoptosis. Archives of Toxicology 2013;87:1157-1180.

Sohail MU, ljaz A, Yousaf MS, Ashraf K, Zaneb H, Aleem M, et al. Alleviation of cyclic heat stress in broilers by dietary supplementation of mannanoligosaccharide and Lactobacillus-based probiotic: dynamics of cortisol, thyroid hormones, cholesterol, C-reactive protein, and humoral immunity. Poultry Science 2010;89:1934-1938.

Thompson SM, Callstrom MR, Butters KA, Knudsen B, Grande JP, Roberts LR, Woodrum DA. Heat stress induced cell death mechanisms in hepatocytes and hepatocellular carcinoma: in vitro and in vivo study. Lasers in Surgery and Medicine 2014;46:290-301. 
Ibtisham F, Zhao Y, Nawab A,

Liguang H, Wu J, Xiao M, Zhao Z, An L

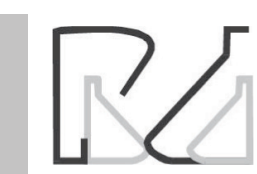

The Effect of High Temperature on Viability,

Proliferation, Apoptosis and Anti-oxidant Status of Chicken Embryonic Fibroblast Cells
Wang X, Cai J, Zhang J, Wang C, Yu A, Chen Y, et al. Acute trimethyltin exposure induces oxidative stress response and neuronal apoptosis in Sebastiscus marmoratus. Aquatic Toxicology 2008;90:58-64.

Wang Z, Cai F, Chen X, Luo M, Hu L, Lu Y. The role of mitochondria-derived reactive oxygen species in hyperthermia-inducedplatelet apoptosis. Plos One 2013;8:e75044.

Wei P, Ma P, Xu Q-S, Bai Q-H, Gu J-G, Xi H, et al. Chitosan oligosaccharides suppress production of nitric oxide in lipopolysaccharide-induced N9 murine microglial cells in vitro. Glycoconjugate Journal 2012;29:285295.

Xiao-Lan Y, Min-Hong Z, Jing-Hai F, Li-Li D, Li-Wen J. Influence of high temperature on oxidative damage and follicle development of laying hens. China Agriculture Science 2012;45:3391-3398.
Xu J, Tang S, Song E, Yin B, Wu D, Bao E. Hsp70 expression induced by Co-Enzyme Q10 protected chicken myocardial cells from damage and apoptosis under in vitro heat stress. Poultry Science 2017;96:14261437.

Zhang G, Gurtu V, Kain SR, Guochen Y. Early detection of apoptosis using a fluorescent conjugate of annexin. BioTechniques 1997;23:525-531.

Zolkipli-Cunningham Z, Falk MJ. Clinical effects of chemical exposures on mitochondrial function. Toxicology 2017;391:90-99.

Zuo L, Christofi FL, Wright VP, Liu CY, Merola AJ, Berliner LJ, et al. Intra- and extracellular measurement of reactive oxygen species produced during heat stress in diaphragm muscle. American Journal of Physiology Cell Physiology 2000;279:C1058-66. 